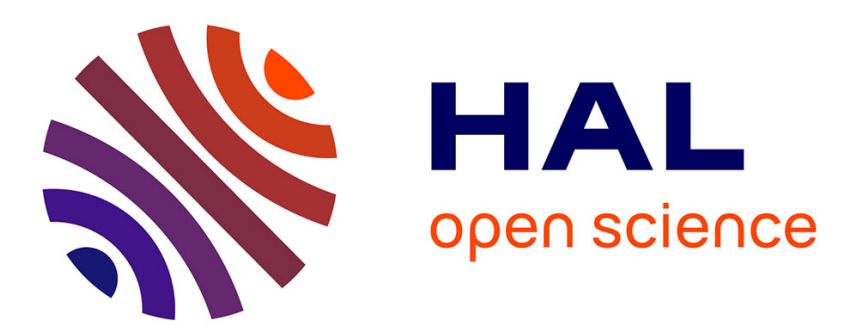

\title{
Recent and future trends in paleopiezometry in the diagenetic domain: Insights into the tectonic paleostress and burial depth history of fold-and-thrust belts and sedimentary basins
}

Nicolas Beaudoin, Olivier Lacombe

\section{To cite this version:}

Nicolas Beaudoin, Olivier Lacombe. Recent and future trends in paleopiezometry in the diagenetic domain: Insights into the tectonic paleostress and burial depth history of fold-and-thrust belts and sedimentary basins. Journal of Structural Geology, 2018, 10.1016/j.jsg.2018.04.001 . hal-01789822

\section{HAL Id: hal-01789822 \\ https://hal.sorbonne-universite.fr/hal-01789822}

Submitted on 11 May 2018

HAL is a multi-disciplinary open access archive for the deposit and dissemination of scientific research documents, whether they are published or not. The documents may come from teaching and research institutions in France or abroad, or from public or private research centers.
L'archive ouverte pluridisciplinaire HAL, est destinée au dépôt et à la diffusion de documents scientifiques de niveau recherche, publiés ou non, émanant des établissements d'enseignement et de recherche français ou étrangers, des laboratoires publics ou privés. 
1 Recent and future trends in paleopiezometry in the diagenetic domain: insights

2 into the tectonic paleostress and burial depth history of fold-and-thrust belts and sedimentary basins

4

5 Nicolas Beaudoin ${ }^{1, *}$, Olivier Lacombe ${ }^{2}$

61 : School of Geographical and Earth Sciences, University of Glasgow, Gregory Building, Lilybank

7 Gardens, G12 8QQ, Glasgow, UK;

82 : Sorbonne Universités, UPMC Univ Paris 06, CNRS, Institut des Sciences de la Terre de Paris (iSTeP),

94 place Jussieu, 75005 Paris, France

10

*nicolas.beaudoin@glasgow.ac.uk

Keywords : paleostress; paleopiezometry; inversion process; tectonic stress; burial estimates; foldand-thrust belt; basin; calcite twinning; stylolites.

Abstract

Paleopiezometry provides an access to the past stress magnitude, key to better understand the behaviour of the earth's crust over long period of time. This contribution presents a review of some paleopiezometric techniques that can be used in the diagenetic domain, in fold-and-thrust belts and sedimentary basins. Calcite twinning and stylolite roughness techniques have been selected and are presented through a critical description of their methodologies, along with approaches to further reconstruct the complete effective stress tensor. Major geological lessons learned over the past decades from published studies are summarized and discussed along with a way forward to potential breakthroughs.

\section{Introduction}

The implication of stress in geological and societal phenomena such as earthquake tectonics, georesources distribution or mechanical behaviour of materials involves different time scales (Barton and Zoback, 1994; Mourgues et al., 2011; Sanderson and Zhang, 1999, 2004; Sibson, 1994; Zoback and Zoback, 1989). To complement current stress measurement unravelling the short-term mechanical behaviour of the upper crust (e.g., Cornet and Burlet, 1992), it is of prime interest to characterize not only the orientation, but also the magnitude of stress - should it be of tectonic, burial or hydrological origin - over long-term time scale (>million years). Past stress magnitude and its evolution during the geological history is however inherently extremely challenging to infer. 
Determination of past stress magnitude associated with the tectonic history of rock masses relies upon establishing a close relationship between the stress magnitude and the development of a conspicuous, commonly encountered structural feature in the rock itself, and calibrating it experimentally. So-called paleopiezometry developed in the second half of the $20^{\text {th }}$ century as a response to the need of picturing the long-term evolution of crustal stress magnitude and of better constraining the mechanical behaviour of geological materials. A paleopiezometer is fundamentally different from the measurement of the instantaneous, local ambient stress in that it potentially records a longer, space- and time-averaged, ancient state of stress that prevailed locally or regionally in the rock during deformation (Lacombe, 2007).

Numerous dynamic paleostress studies were dedicated to reconstruct the succession of past stress in various tectonic contexts using features the development of which could be linked to a stress tensor, with 3 orthonormal principal stresses characterised by orientations (usually one close to vertical) and magnitudes $\left(\sigma_{1} \geq \sigma_{2} \geq \sigma_{3}\right)$. This paper reviews the few paleopiezometers that (1) can be extensively applied to fold-and-thrust belts (FTBs) and sedimentary basins (SBs), (2) have been calibrated in the diagenetic $(P, T)$ domain, and (3) yield the magnitude of the past stress -should the latter be the differential stress or the absolute magnitude of one or more of the principal stressesalong with information on the orientation. Our review therefore excludes paleopiezometric techniques that miss at least one of these criteria, such as dynamic recrystallization of calcite and quartz (Twiss, 1977), dislocation density in calcite (Pfiffner, 1982), crystal subgrain size of halite crystal (Carter and Hansen, 1983), but also approaches calculating stress magnitude from joint interaction geometry (Dyer, 1988) or at the tip of heterogeneities (Gudmundsson, 2003; Olson and Pollard, 1991) or those reconstructing vein opening histories and pressures (Becker et al. 2010; Fall et al., 2016; English \& Laubach, 2017).

This contribution therefore focuses on two paleopiezometers: calcite twinning inversion (Etchecopar, 1984) and stylolite roughness inversion (Schmittbuhl et al., 2004). Because the last reviews on calcite twinning and its potential in tectonic studies date back to Burkhard (1993) and Lacombe (2010), and because the recent developments and outcomes of stylolite roughness inversion and the combined use of both techniques have never been critically discussed, it is timely to present an overview of the principles and limitations of each of these paleopiezometers and how we can go further to reach principal stress magnitudes. We then illustrate what lessons were drawn from paleopiezometric reconstructions of compressional/strike-slip stress regimes as encountered in FTBs and SBs over the past decades, and further discuss the next steps that may lead to breakthroughs in the understanding of the upper crustal stress. 
2. Paleopiezometers applying in the diagenetic domain

\subsection{Calcite twinning paleopiezometry}

Twinning of minerals depends on the magnitude of the applied shear stress. One can make use of this property for evaluating the stress which has been supported by a rock during its history (Tullis, 1980). Calcite is the most sensitive mineral for twinning and the most likely to record tectonic stress history in foreland settings where the outcropping formations are mainly sedimentary rocks. E-twinning is a low-temperature plastic deformation mechanism in calcite. Twinning occurs with a change of form of part of the host crystal by an approximation to simple shear in a particular sense and direction along specific crystallographic planes e $\{01-12\}$. The resulting twinned portion of the crystal bears a mirrored crystallographic orientation to the untwinned portion across the twin plane (Fig.2a-b). Twinning is not thermally activated and is poorly sensitive to either strain rate or confining pressure, and therefore fulfils most requirements for paleopiezometry.

The basis of the widely used Jamison and Spang (1976) technique is that in a sample without any preferred crystallographic orientation, the relative percentages of grains twinned on $0,1,2$ or 3 twin plane(s) depend on the applied $\left(\sigma_{1}-\sigma_{3}\right)$ value. Consequently, knowing these relative percentages in a sample, and assuming a constant Critical Resolved Shear Stress (CRSS) value of 10 MPa for twinning, the magnitude of $\left(\sigma_{1}-\sigma_{3}\right)$ can be estimated. This technique does not take into account the grain size dependence of twinning and assumes uniaxial stress. The technique of Rowe and Rutter (1990) relies on the experimental observation that twinning incidence, twin volume fraction and twin density are sensitive to differential stress; the two first parameters also being grain-size dependent. Such a technique returns the differential stress in a range of temperature from 200 to $800^{\circ} \mathrm{C}$, recently extended down to $20^{\circ} \mathrm{C}$ (Rybacki et al., 2011). None of these paleopiezometers provides the stress orientations and regimes, thus they do not check the mutual compatibility of measured twin systems that may result from a polyphase tectonic history. This limitation turns those techniques in providers of an arguably meaningful maximum bulk differential stress.

Although new techniques of inversion of calcite twins for stress have recently been released (Parlangeau et al., 2018; Yamaji, 2015), the most widely used to date is the Calcite Stress Inversion Technique (CSIT, Etchecopar, 1984). This inversion process assumes that twin gliding along the twinning direction within the twin plane is geometrically comparable to slip along a slickenside lineation within a fault plane (Fig. 1b), and that twinning occurs along a twin plane if the resolved shear stress was greater than the CRSS. The inversion provides the stress tensor that best fits the distribution of measured twinned and untwinned planes (Fig. 1c). The outcome is a reduced stress tensor, i.e. 4 parameters among the 6 of the absolute stress tensor: principal stress orientation and 
stress ratio $\phi$ (defined as $\left.\left(\sigma_{2}-\sigma_{3}\right) /\left(\sigma_{1}-\sigma_{3}\right)\right)$, as well as a dimensionless differential stress. The access to the actual differential stress is provided by the knowledge of the actual value of the CRSS, $10 \pm 4$ $\mathrm{MPa}$, varying with grain size and strain hardening. The isotropic component of the tensor is not retuned with CSIT (Fig. 1d-e). CSIT has been successfully applied to experimentally and naturally deformed samples and has shown its ability to decipher superimposed twinning events (Lacombe and Laurent, 1996; Laurent et al., 2000; Lacombe, 2010 and references therein). Note that the timing of twinning events has only been inferred to date in the light of a (micro)structural sequence, by linking the reconstructed stress orientation to the documented fracture sets (e.g. Amrouch et al., 2010).

\subsection{Stylolite roughness paleopiezometry}

Stylolites are rough surfaces of localized dissolution in the rock (Fig. 1f). The presence of oriented teeth supports genetic models where compaction-related (vertical) or tectonic-related (horizontal) maximum principal stress $\sigma_{1}$ triggers dissolution of the surrounding rock (Alvarez et al., 1978; Fletcher and Pollard, 1981; Merino et al., 1983). During dissolution the stylolite accumulates the less soluble portion of the host, typically clays, that can enhance the dissolution (Bjorkum, 1996; Renard et al., 2001). Stylolites are common features in carbonates where kilometre-length stylolites have been documented (Laronne Ben-Itzhak et al., 2014), but also exist in sandstones, marls and salts, and similar dissolution cleavage can be found in metamorphic rocks (Bell and Cuff, 1989). The typical roughness of a stylolite shows teeth parallel to the $\sigma_{1}$ axis and results from the competition between roughening force, i.e. Zenner pinning where non-soluble heterogeneities (e.g. oxides) resist dissolution (Brouste et al., 2007; Ebner et al., 2010a; Koehn et al., 2007), and smoothening forces: the elastic energy at large-scale and the surface energy at small-scale (Schmittbuhl et al., 2004).

Empiric studies of single-trace stylolites show that stylolite roughness is a signal that displays self-affine properties, the log-log graphical representation of which returns two slopes, defined each by a specific roughness coefficient (Hurst Coefficient) that relates to the scale of observation (Fig. 1g, Schmittbuhl et al., 2004). The two distinct roughness coefficient are linked to the regimes of growth, dominated by the surface energy at small-scale (typically below $1 \mathrm{~mm}$ ) and by the elastic energy at large-scale (above $1 \mathrm{~mm}$ )(Fig. 2b; Ebner et al., 2009ab; 2010b; Rolland et al., 2014; 2012; Schmittbuhl et al., 2004). Stylolite Roughness Inversion Technique (SRIT) builds on the spatial scale at which the roughness growth regime switches from elastic energy to surface energy dominated. This switch, or cross-over length (LC), is related to chemical (surface energy at the solid-fluid interface) and mechanical (Poisson ratio and Young modulus) properties of the host, and to the applied differential and mean stresses (Schmittbuhl et al., 2004). 
Sedimentary stylolites are used to quantify the principal stress closer to the vertical axis that is related to burial, assuming the stress is isotropic in the stylolite plane (e.g. Ebner et al., 2009a). Along tectonic stylolite planes, the stress is anisotropic and a periodic LC is observed and can be reconstructed (Beaudoin et al., 2016; Ebner et al., 2010b). Then, if the vertical stress is known, tectonic stylolites yield principal stress orientations and absolute magnitudes of horizontal principal stresses.

The chemo-mechanical model assumed for SRIT considers that the dissolution occurs on a pressurized plane at the fluid-rock interface, making this paleopiezometer independent on surrounding fluid pressure, hence unable to constrain the complete effective stress tensor (Fig. $1 \mathrm{~h}$-i). Although the underlying growth model is independent on the kinetics of dissolution and on temperature (Schmittbuhl et al., 2004), SRIT relies upon strong mechanical assumptions, especially the Young modulus that can evolve during diagenesis. Some physical statistic studies of natural stylolite roughness show that some stylolites do not yield the self-affine properties (Karcz and Scholz, 2003) predicted by the SRIT growth model. Yet, a recent study has shown that most of the stylolites of which the morphology belongs to classes 2 (seismogram pinning type) and 3 (suture and sharp peaks) of the latest classification (Koehn et al., 2016) are consistent with the SRIT growth model (Beaudoin et al., submitted).

\section{Use of paleopiezometers for burial estimates}

Assessing the burial depth during deformation is a challenging but vital information to constrain depositional, thermal and tectonic histories of FTBs and SBs. In the literature, methods to assess the burial depth (e.g. thermochronology, vitrinite reflectance) and so the vertical stress rely on assuming the past geothermal gradient. Simpler approaches reconstruct the thickness of the past sedimentary column by assuming deformation timing, amount of rock compaction and thickness of eroded strata. Using fluid precipitation temperature reconstructed from Fluid Inclusion Microthermometry (FIM) on mode I microveins, one can assess the depth and timing of the related deformation providing a reliable burial model exists for the considered strata (Anders et al., 2014; Becker et al., 2010; English and Laubach, 2017; Fall et al., 2012; Lespinasse, 1999). Lacombe et al. (2009) used CSIT to estimate maximum burial depth under the assumptions that the LPS-related differential stress prevailed at the maximum burial depth and that the stress in the upper crust is in frictional equilibrium (see section 6.2).

Alternatively, the application of SRIT on sedimentary stylolites in various settings (Jura Mountains: Schmittbuhl et al., 2004; Massif Central: Ebner et al., 2009b; Paris Basin: Rolland et al., 2014; Apennines: Beaudoin et al., 2016; Potiguar Basin, Brazil: Bertotti et al., 2017) yielded $\sigma_{v}$ values straightforwardly converted into paleodepth independently from the past geothermal gradient. 
Sedimentary stylolite grows as long as the maximum principal stress is vertical, and its roughness records the vertical stress prevailing at the time the growth stops, as it equilibrates with stress in about 200 years (Aharonov and Katsman, 2009). Growth can also halt either because of saturation of the stylolite plane, or because the maximum vertical stress was reached. Andrews and Railsback (1997) suggested that very serrate stylolites form earlier than others, and a recent study of a stylolite population in cores from the Paris basin supports that stylolites with localized, large amplitude peak, imprint a lower vertical stress than the stylolites where no such large-amplitude peak occurs and which tend to record the maximum burial vertical stress (Beaudoin et al., submitted). Those examples show that SRIT applied on single-trace sedimentary stylolites provides an accurate access to $\sigma_{v}$, with a potential to decipher a polyphase burial history when considering morphology. This is of prime interest to finer basin burial/uplift history reconstruction (Bertotti et al., 2017), and can also be used in FTBs to reconstruct the maximum depth prevailing before the magnitude of the horizontal stress overcomes the magnitude of the vertical stress (typically at the onset of LPS). It is also possible to distinguish sedimentary stylolites predating or postdating strata tilting, so to reconstruct steps of burial/uplift history at fold-scale.

\section{Reconstruction of the complete paleostress tensor}

As none of the paleopiezometers returns the effective magnitude of all principal stresses at once, it is important to find another way to access the complete stress tensor. A first way is to combine SRIT on coeval sedimentary stylolites and tectonic stylolites, which provides the absolute magnitudes for $\sigma_{v}, \sigma_{H}$ and $\sigma_{h}$. This combination implies either (1) that burial variation during the LPS phase remains negligible, as sedimentary stylolites may record the maximum burial depth until $\sigma 1$ switches from vertical to horizontal as a result of tectonic stress build-up ; or (2) that LPS-related tectonic stylolites developed at the very onset of the LPS phase. SRIT can further help reconstructing the effective stress tensor ( $\sigma^{\prime}=\sigma$ - Pf) if an independent estimate of fluid pressure, as derived from hydrocarbon bearing fluid inclusions, is available.

An established approach to the reconstruction of the effective stress tensor consists in the combination of paleopiezometers with the mechanical properties of rocks that we propose to call the coupled Mohr approach. This approach (Fig. 2) is a graphical / analytical way to combine (1) data about magnitude of differential stress / magnitude of absolute stress / fluid pressure and (2) the orientation of faults / veins with the mechanics of the host rock, i.e. rupture and reactivation criteria derived from mechanical tests. The coupled Mohr approach has been first used on a population of coeval neoformed and reactived faults, the $\left(\sigma_{1}-\sigma_{3}\right)$ Mohr circle fitting the failure curve at the point that corresponds to the angle between $\sigma_{1}$ and the neoformed fault plane, while reactivated fault 
planes plot above the Byerlee's friction line (Fig. 2a). This approach allowed reconstructing the absolute effective stress tensor at the Hoover Dam, USA (Angelier, 1989) and in the Gyeongsang Basin, Korea (Choi et al., 2013). Necessity of coeval neoformed and reactivated faults limits this approach, but one of the two fault populations can be substituted by the differential stress magnitude obtained from CSIT applied on features consistent with the faults (Fig. 2b). This combination returned the complete effective stress tensor in Burgundy, France (Lacombe and Laurent, 1992), in Taiwan (Lacombe, 2001) and in the Bighorn Basin, USA (Amrouch et al., 2011). The fluid pressure can even be derived if the burial depth at the time of twinning is known independently (Amrouch et al., 2011; Beaudoin et al., 2014b). Only one fault populations can be used if combined with the fluid pressure estimates from FIM on oriented tectonic microveins consistent with the faulting (Lespinasse et al., 1995). Fluid pressure estimate can also be combined to rock mechanics and to independent determination of stress orientation and regime to reconstruct the complete stress tensor prevailing during vein reopening (André et al., 2000). This method first uses the angular relationships between the reopened vein planes and the orientation of principal stresses that are assumed to trigger the reopening ( $\theta$ on figure $2 \mathrm{c}$ ) to represent the stress ratio $\phi$. Measured angle $\theta$ (e.g. $\theta_{1}$, between average fracture plane and $\sigma_{1}$ ) is represented as the angle between the intersection $\left(\sigma_{1}-\sigma_{3}\right)$ Mohr circle and the value of the fluid pressure Pf (Upper blue point on Fig. 2c; Jolly and Sanderson, 1997). Second, the Mohr circle is scaled by respecting that the reopened vein poles plot either above the frictional reactivation curve (e.g. Byerlee, grey area on Fig. 2c) and/or that their corresponding normal stress is lower than the fluid pressure (blue area on Fig. 2c). Such a combination of faulting/fracturing, rock mechanics and FIM was used to assess the effective stress tensor in the Rhine graben, France (André et al., 2001) and in Dharwar craton, India (Lahiri and Mamtani, 2016). The use of FIM also potentially allows determination of the depth and relative timing of stress events (Anders et al., 2014; Becker et al., 2010; Fall et al., 2012; 2016).

5. Lessons from paleopiezometry applied to fold-and-thrust belts and sedimentary basins

5.1 Paleopiezometry at fold-and-thrust belt-scale: evidence of forelandward orogenic stress attenuation?

At the scale of an orogen, it is hard to document the way orogenic stresses are transmitted from the hinterland to the foreland. Yet stress magnitude is a key factor controlling fracture distribution hence large-scale geofluid migration (Beaudoin et al., 2014a). Calcite twinning paleopiezometry has been used in various ranges to quantify differential stress magnitude across the foreland, either deformed (i.e. FTB) or stable. Several studies show a rapid decrease of the 
differential stress magnitude in the first hundreds kilometres forelandward from the hinterland/foreland boundary, as for instance in the Sevier and Appalachian forelands (Craddock et al., 1993; van der Pluijm et al., 1997), where the authors concluded that the similarity of stress patterns observed in different forelands supports that the range acts as a filter for the stress regardless of the tectonic style in the orogen. A decreasing trend of the differential stress is also documented in the Ouachita range across the Tennessee salient (Fig. 3a, Hnat and van der Pluijm, 2011), in the Hellenides range (Xypolias and Koukouvelas, 2005; Fig.3c) and in the north Pyrenean foreland (Lacombe et al., 1996; Rocher et al., 2000). In the Zagros range, yet, differential stress was instead rather low and constant across the deformed foreland and in part of the hinterland (Fig. 3b, Lacombe et al., 2007), supporting 1- a regional decoupling between the basement and the sedimentary cover and fold development at very low differential stresses (buckling) and 2- that the differential stress attenuation observed in other orogenic forelands may not be a general rule.

5.2 Paleopiezometry at the fold-scale: evidence for stress compartmentalization and horizontal stress anisotropy?

Long-term evolution of stress magnitudes and regimes during folding has been addressed through numerical modelling (Albertz and Sanz, 2012; Guiton et al., 2003; Sassi et al., 2012; Smart et al., 2012). Yet, there are few tectonic paleostress reconstructions on natural folds (Amrouch et al., 2011; Arboit et al., 2017; Beaudoin et al., 2012; Lacombe, 2001). The application of CSIT and of the coupled Mohr approach in the well-constrained fracture history frame of the Sheep Mountain Anticline (USA) was pioneer in reconstructing the evolution of stress magnitudes during the Laramide tectonic history (Amrouch et al., 2011). The stress evolution highlights some local stress perturbation effects, such as at the tip of the propagating underlying basement thrust (Fig 4a). The study also shows how the coupled Mohr approach helps quantify past fluid (over) pressure (Beaudoin et al., 2014b), offering an alternative approach to classical barometric techniques such as FIM (e.g Hooker et al., 2015). The combination of CSIT on veins and SRIT on both sedimentary and tectonic stylolites from the Monte Nero Anticline (Central Apennines, Beaudoin et al., 2016) documents that stress may vary in a more complex way than previously documented (Fig. 4b). Upon the assumption that during a given tectonic stage (e.g. LPS), calcite twins and tectonic stylolites sharing a common orientation of $\sigma_{1}$ developed in a sequence occurring at similar depth (fig. 4b), then the Monte Nero case shows an anisotropic variation of the stress in the horizontal plane during stress build-up, even prior to folding. The results also demonstrate how erosion and local sediment redistribution or structural burial in the overturned forelimb can locally switch the stress regime from contractional to extensional (Fig. 4b). These two examples illustrate how powerful is the combination of paleopiezometers to better capture and understand the stress and burial history 
during folding, but also raise questions about the timing and the significance of the stress record by the distinctive paleopiezometers.

\section{Discussion and way forward}

\subsection{Unlocking methodological limitations}

The paleopiezometers we presented are likely to improve by better constraining the process of stress record through monitored experiments, both in numerical or laboratory environments. As an example, CSIT is based on the assumption of a CRSS for twinning, which value has never been calibrated for a full range of grain size and is still a matter of debate (De Bresser et al., 1997, Ferrill, 1998; Covey-Crump et al., 2017). Also, the extension of SRIT to multi-trace stylolites, or to anamostosis network, will be possible once the physical meaning behind these phenomena (merging, saturation, reactivation of stylolite planes) will be understood in a mechanical way. Recent imagery techniques, such as Electron Back Scatter Diffractometer or Xray MicroComputed tomography, can slightly improve data acquisition, but they are mainly promising tools to observe the live deformation phenomenon under controlled conditions, paving the way to a better calibration of the stress-deformation relationship, reduction of uncertainty and possible separation of the various components of the recorded stress tensor. New paleopiezometers can also be developed, as illustrated by the recent study of rhythmically-spaced textures found in some dolostones (Zebra Dolomite), of which the banding spacing has been related to the applied $\sigma_{v}$ and the permeability during crystallisation (Kelka et al., 2017).

\subsection{From local paleopiezometric record to long-term crustal rheology}

Figure 5 presents a new compilation of differential stress estimates from orogenic contexts (horizontal $\sigma_{1}$, strike-slip or compressional stress regimes) as a function of paleodepth of deformation, regardless of the paleopiezometers used and of their own limitations (Table S1); it is an update of the previous release by Lacombe (2007) and includes as such most of the stress estimates published over the last 10 years while widening the range of encompassed paleopiezometers.

At the first order, differential stress increases with depth, which supports a long-term frictional behavior of the upper crust, with higher stress, hence higher crustal strength, in compressional regime than in strike-slip regime. In addition, most differential stress data plot along, or close to, the stress-depth curves predicted for a critically stressed crust for a range of friction coefficients and pore pressure ratios, while only few reflect stress level beyond the frictional yield (Lacombe, 2007). This clear increase of differential stress with depth casts doubt onto the interpretation of forelandward orogenic stress attenuation (section 3.b) unless the reported magnitudes of differential stress have been properly normalized to the depth of deformation. If the decreasing 
trend is true, it could well reflect a forelandward orogenic stress attenuation as proposed or, alternatively, a constant (intraplate) background stress level significantly disturbed by the stress accumulation near the crustal thrust at the hinterland-foreland boundary (Lacombe et al., 1996). This debate emphasizes the need for combining such data with new numerical modelling of how the stress is transmitted from the orogen to the (variably coupled) foreland. Also, it illustrates that assessing the depth at the time of the deformation is a key parameter in paleopiezometry.

\subsection{Timing and time-scale of the paleopiezometric record}

A central point of discussion concerns the timing of paleopiezometric record. This point encompasses the time-scale at which the various paleopiezometers record stress (i.e., duration and rate, progressive vs instantaneous stress record), but also the timing of the stress event within the geological history (i.e., dating).

Paleopiezometers such as CSIT and to a greater extent the coupled Mohr approach likely return a maximum stress value possibly following a long-lasting stress build-up during a given tectonic event. In contrast, SRIT grants a potential access to different time of deformation when applied to a population, as individual stylolites act as pseudo-snapshots of stress. The comparison/combination of the different paleopiezometers offers a glimpse of that access to stress to various time-scales, which can lead to a better recognition of the effect of transient phenomena on the recorded stress such as seepage forces (e.g., Cobbold and Rodrigues, 2007; Mourgues and Cobbold, 2003).

Concerning the timing of the stress record - a blind spot for most present paleopiezometersrecent development in absolute dating of vein calcite cements using $\mathrm{U} / \mathrm{Pb}$ technique (Hansman et al., 2018; Parrish et al., 2018) can well be one next breakthrough in paleostress studies. Indeed, absolute dating can be conducted on calcite cement from (1) veins from which stress magnitudes can be characterized using CSIT, and (2) veins developing at the tip of the coeval stylolites, likely from the deposition of the dissolved material. Such developments would be a major addition to the inference of deformation age by integrating cement precipitation temperature from FIM to burial models that rely on past geothermal gradient (Anders et al., 2014; Laubach et al., 2016).

Accessing the absolute timing of deformation would help solve some of the remaining questions, for example about the mechanical-based $4 \mathrm{D}$ models that govern stress distribution in reservoirs and at a larger scale in orogenic forelands, stress perturbations related to faults, or to discuss the paradigm of the averaged isotropic effect of the fluid pressure on the stress tensor. Future breakthrough should come with the multiplication of data acquisition combining 
paleopiezometers, with the coupling to absolute dating, and with a better calibration and understanding of the microstructures paleopiezometry is based on.

\section{Acknowledgments}

Authors wish to thank the Editor lan Alsop and two anonymous reviewers for their useful comments and suggestions that improved the quality of the paper. Authors also thank D. Koehn for fruitful discussion throughout the writing of this paper.

\section{References}

Aharonov, E., Katsman, R., 2009. Interaction between pressure solution and clays in stylolite development: Insights from modeling. American Journal of Science 309, 607-632.

Albertz, M., Sanz, P.F., 2012. Critical state finite element models of contractional fault-related folding: Part 2. Mechanical analysis. Tectonophysics 576-577, 150-170.

Alvarez, W., Engelder, T., Geiser, P.A., 1978. Classification of solution cleavage in pelagic limestones. Geology 6, 263-266.

Amrouch, K., Lacombe, O., Bellahsen, N., Daniel, J.-M., Callot, J.-P., 2010. Stress and strain patterns, kinematics and deformation mechanisms in a basement-cored anticline: Sheep Mountain Anticline, Wyoming., Tectonics 29, TC1005, doi:10.1029/2009TC002525.

Amrouch, K., Beaudoin, N., Lacombe, O., Bellahsen, N., Daniel, J.-M., 2011. Paleostress magnitudes in folded sedimentary rocks. Geophysical Research Letters 38, L17301, doi:10.1029/2011GL048649.

Anders, M.H., Laubach, S.E., Scholz, C.H., 2014. Microfractures: A review. Journal of Structural Geology 69, 377-394.

André, A.-S., Sausse, J., Lespinasse, M., 2001. New approach for the quantification of paleostress magnitudes: application to the Soultz vein system (Rhine graben, France). Tectonophysics 336, 215-231.

Andrews, L.M., Railsback, L.B., 1997. Controls on stylolite development: morphologic, lithologic, and temporal evidence from bedding-parallel and transverse stylolites from the US Appalachians. The Journal of Geology 105, 59-73.

Angelier, J., 1989. From orientation to magnitudes in paleostress determinations using fault slip data. Journal of structural geology 11, 37-50.

Arboit, F., Amrouch, K., Morley, C., Collins, A.S., King, R., 2017. Palaeostress magnitudes in the Khao Khwang fold-thrust belt, new insights into the tectonic evolution of the Indosinian orogeny in central Thailand. Tectonophysics 710, 266-276.

Barton, C.A., Zoback, M.D., 1994. Stress perturbations associated with active faults penetrated by boreholes: Possible evidence for near-complete stress drop and a new technique for stress magnitude measurement. Journal of Geophysical Research: Solid Earth 99, 9373-9390.

Beaudoin, N., Bellahsen, N., Lacombe, O., Emmanuel, L., Pironon, J., 2014a. Crustal-scale fluid flow during the tectonic evolution of the Bighorn Basin (Wyoming, USA). Basin Research 26, 403435. 
Beaudoin, N., Koehn, D., Lacombe, O., Lecouty, A., Billi, A., Aharonov, E., Parlangeau, C., 2016. Fingerprinting stress: Stylolite and calcite twinning paleopiezometry revealing the complexity of progressive stress patterns during folding-The case of the Monte Nero anticline in the Apennines, Italy. Tectonics 35, 1687-1712.

Beaudoin, N., Lacombe, O., Bellahsen, N., Amrouch, K., Daniel, J.-M., 2014b. Evolution of pore-fluid pressure during folding and basin contraction in overpressured reservoirs: Insights from the Madison-Phosphoria carbonate formations in the Bighorn Basin (Wyoming, USA). Marine and Petroleum Geology 55, 214-229.

Beaudoin, N., Leprêtre, R., Bellahsen, N., Lacombe, O., Amrouch, K., Callot, J.-P., Emmanuel, L., Daniel, J.-M., 2012. Structural and microstructural evolution of the Rattlesnake Mountain Anticline (Wyoming, USA): New insights into the Sevier and Laramide orogenic stress buildup in the Bighorn Basin. Tectonophysics 576-577, 20-45.

Beaudoin, N., Gasparrini, M., David, M.-E., Lacombe, O., Koehn, D., submitted. Bedding-parallel stylolites as a tool to unravel maximum burial depth in sedimentary basins: application to Middle Jurassic carbonate reservoirs in the Paris basin, submitted to GSA Bulletin.

Becker, S.P., Eichhubl, P., Laubach, S.E., Reed, R.M., Lander, R.H., Bodnar, R.J., 2010. A 48 m.y. history of fracture opening, temperature, and fluid pressure: Cretaceous Travis Peak Formation, East Texas basin. Geological Society of America Bulletin 122, 1081-1093.

Bell, T., Cuff, C., 1989. Dissolution, solution transfer, diffusion versus fluid flow and volume loss during deformation/metamorphism. Journal of Metamorphic Geology 7, 425-447.

Bertotti, G., de Graaf, S., Bisdom, K., Oskam, B., Vonhof, H.B., Bezerra, F.H., Reijmer, J.J., Cazarin, C.L., 2017. Fracturing and fluid-flow during post-rift subsidence in carbonates of the Jandaíra Formation, Potiguar Basin, NE Brazil. Basin Research 29, 836-853.

Bjorkum, P.A., 1996. How important is pressure in causing dissolution of quartz in sandstones? Journal of Sedimentary Research 66.

Brouste, A., Renard, F., Gratier, J.-P., Schmittbuhl, J., 2007. Variety of stylolites' morphologies and statistical characterization of the amount of heterogeneities in the rock. Journal of Structural Geology 29, 422-434.

Burkhard, M., 1993. Calcite twins, their geometry, appearance and significance as stress-strain markers and indicators of tectonic regime: a review. Journal of structural geology 15, 351368.

Carter, N.L., Hansen, F.D., 1983. Creep of rocksalt. Tectonophysics 92, 275-333.

Choi, P.-y., Angelier, J., Cadet, J.-P., Hwang, J.-H., Sunwoo, C., 2013. Change of stress magnitudes during the polyphase tectonic history of the Cretaceous Gyeongsang basin, southeast Korea. Bulletin de la Société Géologique de France 184, 467-484.

Cobbold, P.R., Rodrigues, N., 2007. Seepage forces, important factors in the formation of horizontal hydraulic fractures and bedding-parallel fibrous veins ('beef'and 'cone-in-cone'). Geofluids 7, 313-322.

Cornet, F., Burlet, D., 1992. Stress field determinations in France by hydraulic tests in boreholes. Journal of Geophysical Research: Solid Earth 97, 11829-11849.

Covey-Crump, S., Schofield, P., Oliver, E., 2017. Using neutron diffraction to examine the onset of mechanical twinning in calcite rocks. Journal of Structural Geology, 100, 77-97

Craddock, J.P., Jackson, M., Pluijm, B.A., Versical, R.T., 1993. Regional shortening fabrics in eastern North America: Far-field stress transmission from the Appalachian-Ouachita Orogenic Belt. Tectonics 12, 257-264. 
De Bresser, J.H.P., Spiers, C.J., 1997. Strength characteristics of the $r, f$ and $c$ slip systems in calcite. Tectonophysics 272, 1-23.

Dyer, R., 1988. Using joint interactions to estimate paleostress ratios. Journal of Structural Geology 10, 685-699.

Ebner, M., Koehn, D., Toussaint, R., Renard, F., 2009a. The influence of rock heterogeneity on the scaling properties of simulated and natural stylolites. Journal of Structural Geology 31, $72-$ 82.

Ebner, M., Koehn, D., Toussaint, R., Renard, F., Schmittbuhl, J., 2009b. Stress sensitivity of stylolite morphology. Earth and Planetary Science Letters 277, 394-398.

Ebner, M., Piazolo, S., Renard, F., Koehn, D., 2010a. Stylolite interfaces and surrounding matrix material: Nature and role of heterogeneities in roughness and microstructural development. Journal of Structural Geology 32, 1070-1084.

Ebner, M., Toussaint, R., Schmittbuhl, J., Koehn, D., Bons, P., 2010b. Anisotropic scaling of tectonic stylolites: A fossilized signature of the stress field? Journal of Geophysical Research 115, B06403.

English, J.M., Laubach, S.E., 2017. Opening-mode fracture systems: insights from recent fluid inclusion microthermometry studies of crack-seal fracture cements. Geological Society, London, Special Publications 458, 257-272.

Etchecopar, A., 1984. Etude des états de contrainte en tectonique cassante et simulations de déformations plastiques: approche mathématique.

Fall, A., Eichhubl, P., Cumella, S.P., Bodnar, R.J., Laubach, S.E., Becker, S.P., 2012. Testing the basincentered gas accumulation model using fluid inclusion observations: Southern Piceance Basin, Colorado. AAPG Bulletin 96, 2297-2318.

Fall, A., Ukar, E., Laubach, S.E., 2016. Origin and timing of Dauphiné twins in quartz cement in fractured sandstones from diagenetic environments: Insight from fluid inclusions. Tectonophysics 687, 195-209.

Ferrill, D.A., 1998. Critical re-evaluation of differential stress estimates from calcite twins in coarsegrained limestones. Tectonophysics $285,77-86$.

Fletcher, R.C., Pollard, D.D., 1981. Anticrack model for pressure solution surfaces. Geology 9, 419424.

Gudmundsson, A., 2003. Surface stresses associated with arrested dykes in rift zones. Bulletin of Volcanology 65, 606-619.

Guiton, M.L.E., Sassi, W., Leroy, Y.M., Gauthier, B.D.M., 2003. Mechanical constraints on the chronology of fracture activation in folded Devonian sandstone of the western Moroccan Anti-Atlas. Journal of Structural Geology 25, 1317-1330.

Hansman, R.J., Albert, R., Gerdes, A., Ring, U., 2018. Absolute ages of multiple generations of brittle structures by U-Pb dating of calcite. Geology 46, 207-210.

Hnat, J.S., van der Pluijm, B.A., 2011. Foreland signature of indenter tectonics: Insights from calcite twinning analysis in the Tennessee salient of the Southern Appalachians, USA. Lithosphere 3, 317-327.

Hooker, J.N., Larson, T.E., Eakin, A., Laubach, S.E., Eichhubl, P., Fall, A., Marrett, R., 2015. Fracturing and fluid flow in a sub-décollement sandstone; or, a leak in the basement. Journal of the Geological Society 172, 428-442. 
Jamison, W.R., Spang, J.H., 1976. Use of calcite twin lamellae to infer differential stress. Geological Society of America Bulletin 87, 868-872.

Jolly, R., Sander Jamison, W.R., Spang, J.H., 1976. Use of calcite twin lamellae to infer differential stress. Geological Society of America Bulletin 87, 868-872.son, D., 1997. A Mohr circle construction for the opening of a pre-existing fracture. Journal of Structural Geology 19, 887892.

Karcz, Z., Scholz, C.H., 2003. The fractal geometry of some stylolites from the Calcare Massiccio Formation, Italy. Journal of Structural Geology 25, 1301-1316.

Kelka, U., Veveakis, M., Koehn, D., Beaudoin, N., 2017. Zebra rocks: compaction waves create ore deposits. Scientific reports 7, 14260.

Koehn, D., Renard, F., Toussaint, R., Passchier, C., 2007. Growth of stylolite teeth patterns depending on normal stress and finite compaction. Earth and Planetary Science Letters 257, 582-595.

Koehn, D., Rood, M.P., Beaudoin, N., Chung, P., Bons, P.D., Gomez-Rivas, E., 2016. A new stylolite classification scheme to estimate compaction and local permeability variations. Sedimentary Geology 346, 60-71.

Lacombe, O., 2001. Paleostress magnitudes associated with development of mountain belts: Insights from tectonic analyses of calcite twins in the Taiwan Foothills. Tectonics 20, 834-849.

Lacombe, O., 2007. Comparison of paleostress magnitudes from calcite twins with contemporary stress magnitudes and frictional sliding criteria in the continental crust: Mechanical implications. Journal of Structural Geology 29, 86-99.

Lacombe O., 2010, Calcite twins, a tool for tectonic studies in thrust belts and stable orogenic forelands. Oil and Gas Science and Technology, 65, 6, 809-838

Lacombe, O., Amrouch, K., Mouthereau, F., Dissez, L., 2007. Calcite twinning constraints on late Neogene stress patterns and deformation mechanisms in the active Zagros collision belt. Geology 35, 263-266.

Lacombe, O., Laurent, P., 1992. Determination of principal stress magnitudes using calcite twins and rock mechanics data. Tectonophysics 202, 83-93.

Lacombe, O., Laurent, P., Rocher, M., 1996. Magnitude de la contrainte déviatorique pyrénéenne dans I'avant-pays nord-pyrénéen. CR Acad. Sci., Ser. Ila 322, 229-235.

Lacombe O., Laurent P., 1996. Determination of deviatoric stress tensors based on inversion of calcite twin data from experimentally deformed monophase samples: preliminary results. Tectonophysics, 255, 189-202

Lahiri, S., Mamtani, M.A., 2016. Scaling the 3-D Mohr circle and quantification of paleostress during fluid pressure fluctuation-Application to understand gold mineralization in quartz veins of Gadag (southern India). Journal of Structural Geology 88, 63-72.

Laronne Ben-Itzhak, L., Aharonov, E., Karcz, Z., Kaduri, M., Toussaint, R., 2014. Sedimentary stylolite networks and connectivity in limestone: Large-scale field observations and implications for structure evolution. Journal of Structural Geology 63, 106-123.

Laubach, S.E., Fall, A., Copley, L.K., Marrett, R., Wilkins, S.J., 2016. Fracture porosity creation and persistence in a basement-involved Laramide fold, Upper Cretaceous Frontier Formation, Green River Basin, USA. Geological Magazine 153, 887-910.

Laurent P., Kern H., Lacombe O., 2000. Determination of deviatoric stress tensors based on inversion of calcite twin data from experimentally deformed monophase samples. II : uniaxial and triaxial stress experiments. Tectonophysics, 327, 131-148. 
Lespinasse, M., 1999. Are fluid inclusion planes useful in structural geology? Journal of Structural Geology 21, 1237-1243.

Lespinasse, M., Cathelineau, M., 1995. Paleostress magnitudes determination by using fault slip and fluid inclusions planes data. Journal of Geophysical Research: Solid Earth 100, 3895-3904.

Merino, E., Ortoleva, P., Strickholm, P., 1983. Generation of evenly-spaced pressure-solution seams during (late) diagenesis: A kinetic theory. Contributions to Mineralogy and Petrology 82, 360-370.

Mourgues, R., Cobbold, P.R., 2003. Some tectonic consequences of fluid overpressures and seepage forces as demonstrated by sandbox modelling. Tectonophysics 376, 75-97.

Mourgues, R., Gressier, J.B., Bodet, L., Bureau, D., Gay, A., 2011. "Basin scale" versus "localized" pore pressure/stress coupling - Implications for trap integrity evaluation. Marine and Petroleum Geology 28, 1111-1121.

Olson, J.E., Pollard, D.D., 1991. The initiation and growth of en echelon veins. Journal of Structural Geology 13, 595-608.

Parlangeau, C., Lacombe, O., Schueller, S., Daniel, J.-M., 2018. Inversion of calcite twin data for paleostress orientations and magnitudes: A new technique tested and calibrated on numerically-generated and natural data. Tectonophysics 722, 462-485

Parrish, R.R., Parrish, C.M., Lasalle, S., 2018. Vein calcite dating reveals Pyrenean orogen as cause of Paleogene deformation in southern England. Journal of the Geological Society, jgs20172107.

Pfiffner, O.A., 1982. Deformation mechanisms and flow regimes in limestones from the Helvetic zone of the Swiss Alps. Journal of structural Geology 4, 429-442.

Renard, F., Dysthe, D., Feder, J., Bjørlykke, K., Jamtveit, B., 2001. Enhanced pressure solution creep rates induced by clay particles: Experimental evidence in salt aggregates. Geophysical Research Letters 28, 1295-1298.

Rocher, M., Lacombe, O., Angelier, J., Deffontaines, B.t., Verdier, F., 2000. Cenozoic folding and faulting in the south Aquitaine Basin (France): insights from combined structural and paleostress analyses. Journal of Structural Geology 22, 627-645.

Rolland, A., Toussaint, R., Baud, P., Conil, N., Landrein, P., 2014. Morphological analysis of stylolites for paleostress estimation in limestones. International Journal of Rock Mechanics and Mining Sciences 67, 212-225.

Rolland, A., Toussaint, R., Baud, P., Schmittbuhl, J., Conil, N., Koehn, D., Renard, F., Gratier, J.-P., 2012. Modeling the growth of stylolites in sedimentary rocks. Journal of Geophysical Research: Solid Earth 117, B06403, doi:10.1029/2011JB009069.

Rybacki, E., Janssen, C., Wirth, R., Chen, K., Wenk, H.-R., Stromeyer, D., Dresen, G., 2011. Lowtemperature deformation in calcite veins of SAFOD core samples (San Andreas Fault)microstructural analysis and implications for fault rheology. Tectonophysics 509, 107-119.

Sanderson, D.J., Zhang, X., 1999. Critical stress localization of flow associated with deformation of well-fractured rock masses, with implications for mineral deposits. Geological Society, London, Special Publications 155, 69-81.

Sanderson, D.J., Zhang, X., 2004. Stress-controlled localization of deformation and fluid flow in fractured rocks. Geological Society, London, Special Publications 231, 299-314. 
Sassi, W., Guiton, M.L.E., Leroy, Y.M., Daniel, J.M., Callot, J.P., 2012. Constraints on bed scale fracture chronology with a FEM mechanical model of folding: The case of Split Mountain (Utah, USA). Tectonophysics 576-577, 197-215.

Schmittbuhl, J., Renard, F., Gratier, J.P., Toussaint, R., 2004. Roughness of stylolites: implications of 3D high resolution topography measurements. Phys Rev Lett 93, 238501.

Sibson, R.H., 1994. Crustal stress, faulting and fluid flow. Geological Society, London, Special Publications 78, 69-84.

Smart, K.J., Ferrill, D.A., Morris, A.P., McGinnis, R.N., 2012. Geomechanical modeling of stress and strain evolution during contractional fault-related folding. Tectonophysics 576-577, 171-196.

Tullis, T.E., 1980. The use of mechanical twinning in minerals as a measure of shear stress magnitudes. Journal of Geophysical Research: Solid Earth 85, 6263-6268.

Twiss, R.J., 1977. Theory and applicability of a recrystallized grain size paleopiezometer, Stress in the Earth. Springer, pp. 227-244.

van der Pluijm, B.A., Craddock, J.P., Graham, B.R., Harris, J.H., 1997. Paleostress in cratonic North America: Implications for deformation of continental interiors. Science 277, 794-796.

Xypolias, P., Koukouvelas, I.K., 2005. Paleostress magnitude in a fold-thrust belt (External Hellenides, Greece): evidence from twinning in calcareous rocks.

Yamaji, A., 2015. Generalized Hough transform for the stress inversion of calcite twin data. Journal of Structural Geology 80, 2-15.

Zoback, M.L., Zoback, M.D., 1989. Tectonic stress field of the continental United States. Geological Society of America Memoirs 172, 523-540.

Figure captions

Figure 1 - Summary of the selected paleopiezometers valid in the diagenetic domains. a-e) Calcite twinning inversion technique CSIT (Etchecopar, 1984): a) microphotograph of twinning in calcite crystals, black bar is $0.1 \mathrm{~mm}, \mathrm{~b})$ sketch of a twin lamella (C/C' : optical axis of host crystal/twin lamella, respectively), c) Distribution of twinned and untwinned planes measured in a calcite crystal population regarding the normalized resolved shear stress (RSS) vs the normal stress on, RSS/CRSS :

Resolved shear stress /Critical RSS, d) Outcome of CSIT in term of stress magnitude represented on a schematic Mohr diagram ( $\tau=$ tangential vs $\sigma n=$ normal stress), red arrows represent uncertainty about the values of the effective principal stresses, e) outputs and remarks. $f-i)$ Stylolite roughness inversion technique SRIT (Schmittbuhl et al., 2004): f) microphotograph of a stylolite, black bar is 5 $\mathrm{mm}, \mathrm{g}$ ) top: ideal roughness signal split into a sum of large wavelength signal and small wavelength signal, bottom: corresponding signal analysis by Fast Fourier Transform (Fourier Power Spectrum $(P(k))$ vs Spatial Frequency $\left.\mathrm{k}\left(\mathrm{mm}^{-1}\right)\right)$ that shows two different slopes with coefficient factor typical for elastic energy at large scale and surface energy at small scale, and a Crossover Length Lc used to 
calculate the magnitude of the principal stress parallel to the peaks, h) Outcome of SRIT in term of stress magnitude represented on a schematic Mohr diagram, i) outputs and remarks.

588

589

590

591

592

593

594

595

596

597

598

599

600

601

602

603

604

605

606

607

608

609

610

611

612

613

614

615

Figure 2 - Illustration of the coupled Mohr approach to obtain the complete effective stress tensor. $\alpha$ represents the measured angle between $\sigma_{1}$ and the considered fracture plane, the red square correspond to the tangency to the failure criterion. a) Original method using populations of neoformed and reactivated faults (Angelier, 1989); b) Use of CSIT on oriented veins (Amrouch et al., 2011); c) combination of fluid pressure estimate from fluid inclusion microthermometry, frictional reactivation curve and reopened vein orientation (André et al., 2001). $\theta_{1 \text { or } 2}$ represents the angle between reopened veins strike and the $\sigma_{1}$ or 2 , blue points correspond to the intersection between the Mohr circles and the measured fluid pressure, grey and blue areas correspond to the domain wherein veins can be reopened.

Figure 3 - Case studies illustrating the reconstructed evolution of differential stress $\left(\sigma_{1}-\sigma_{3}\right)$ vs distance to the hinterland/foreland boundary using calcite twinning paleopiezometry. a) Exponential decrease of the differential stress in the Ouachita foreland using Jamison and Spang technique (triangles from Hnat et al., 2013, squares from van der Pluijm et al., 1997); b) Nearly stable differential stress in the hinterland and FTB of the Zagros using CSIT (Lacombe et al., 2007). An alternative interpretation suggesting a decrease is also proposed; c) Decreasing differential stress in the first $100 \mathrm{~km}$ of External Hellenides FTB, using Jamison and Spang technique (Xypolias and Koukouvelas, 2005).

Figure 4-Case studies illustrating the reconstruction of the evolution of the principal stress orientations and effective or absolute stress magnitudes at the fold scale, along with schematic representation of the deformation pattern at each stage of deformation (including folding), with neoformed/reactivated features in red, and corresponding Mohr circle aligned. a) case of the Sheep Mountain Anticline, USA (Amrouch et al., 2011), where the coupled Mohr approach allows reconstruction of the effective stress tensor at each stage of deformation $\left(\sigma^{\prime}=\sigma-P f\right)$ in the strata from fold limbs. b) case of the Monte Nero Anticline, Italy, where SRIT and CSIT are combined and depth is derived from SRIT on sedimentary stylolites (values re-evaluated after Beaudoin et al., 2016). Paleostress results are reported on the Mohr diagram (SRIT, grey ; CSIT, white) as absolute stress magnitudes $\left(\sigma_{H}\right.$, maximum horizontal principal stress; $\sigma_{h}$, minimum horizontal principal stress ; $\sigma_{\mathrm{v}}$, vertical stress; $\left.\sigma_{\mathrm{xc}}, \mathrm{CSIT} ; \sigma_{\mathrm{xS}}, \mathrm{SRIT}\right)$.

Figure 5 - Log-log plot of differential stress (MPa) obtained from paleopiezometry in orogenic forelands and basins versus independent estimates of the depth $(\mathrm{km})$ at the time of deformation, from data available in the literature. The frictional stress equilibrium curves according to the stress 
619 regime, friction coefficient $(\mu)$ and pore fluid ratio $(\lambda)$ are reported as solid $(d r y, \lambda=0)$ or dashed 620 (hydrostatic fluid pressure, $\lambda=0.38$ ) lines, the colour of which refers to the stress regime and $\mu$ value. 621 The number next to the black square is the case study ID and refers to table S1. ID colour refers to 622 the paleopiezometric technique used. The error bars correspond either to the range of stress/depth 623 values reported in the literature for each case study or to an arbitrary $10 \%$ of the value if a range 624 was not available, the colours are related to the stress regime. Frames (SS : strike-slip, SS/R : strike625 slip /compressional, i.e., transpressional ; R : compressional) correspond to the stress regime 626 domains as derived from the plot. 


\section{Figure 1}

Calcite Twinning Inversion

a)

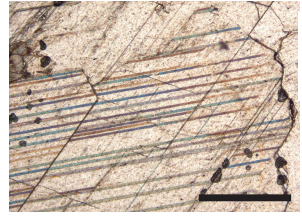

c) Normalized RSS 0,5

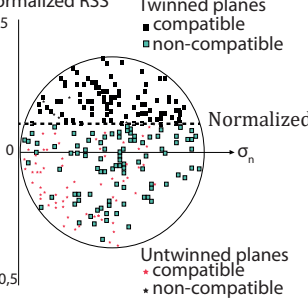

b)

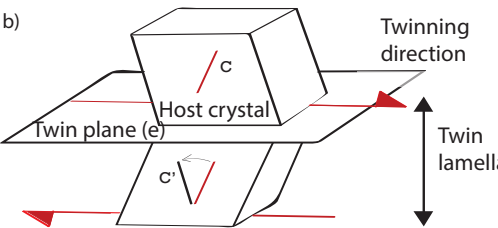

d)

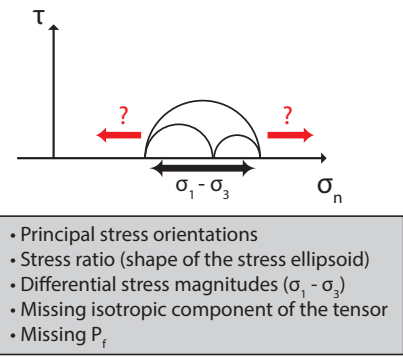

Stylolite Roughness Inversion
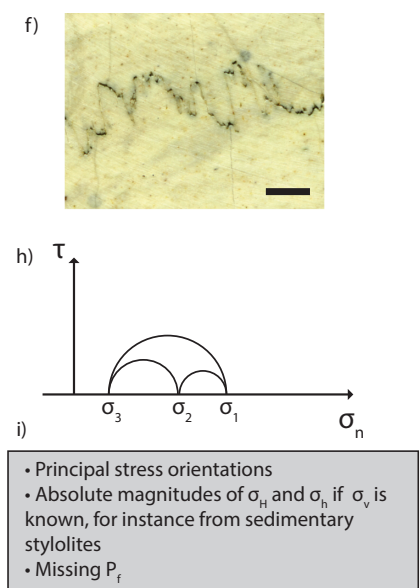

g)
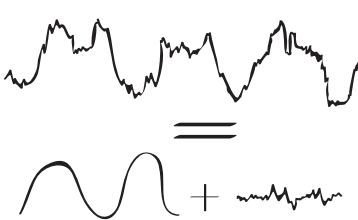

$\mathrm{P}(\mathrm{k})$

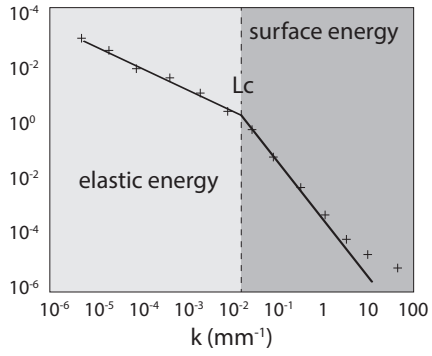


a)

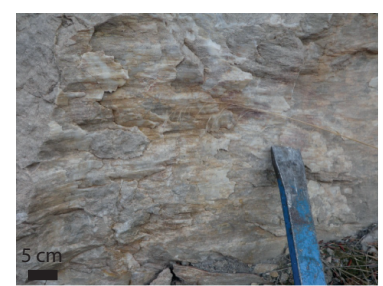

Striated faults

Neoformed + reactivated $+$

rock mechanics

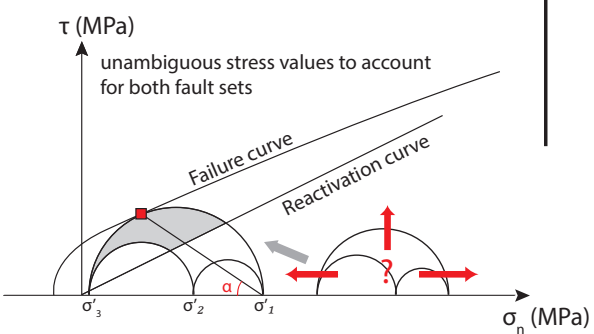

b)

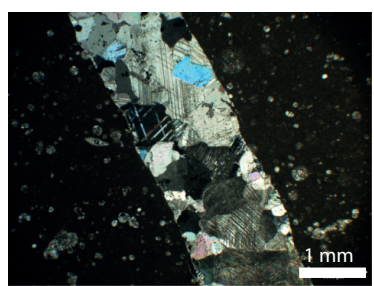

Calcite twins (CSIT) from veins $+$

rock mechanics

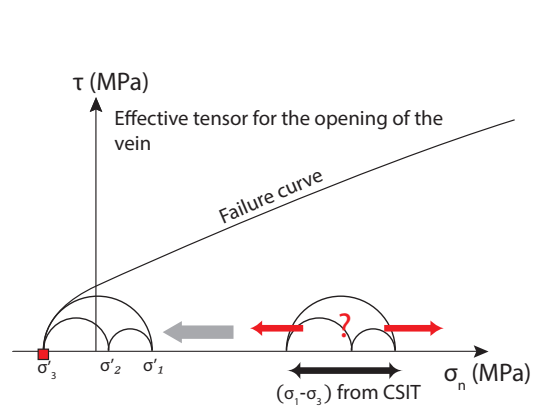

c)

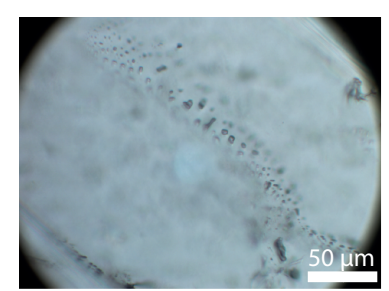

Pressure estimate from fluid inclusion microthermetry

Stress orientation and regime estimate $+$

rock mechanics

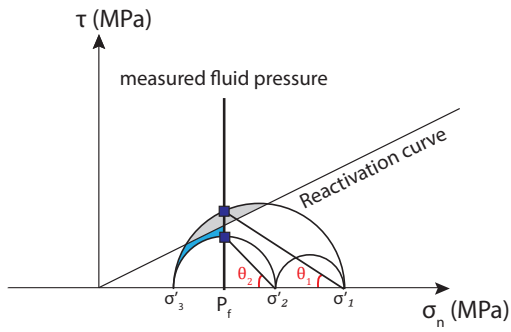




\section{Figure 3 \\ a) 3}

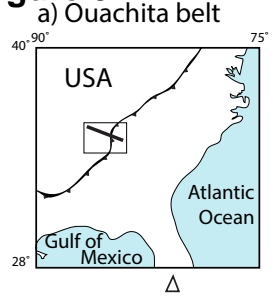

$-\Delta \frac{\Delta}{\Delta}-\Delta_{\Delta}^{\Delta}-\Delta_{\Delta}^{\Delta}-\Delta_{-50}^{\Delta}$
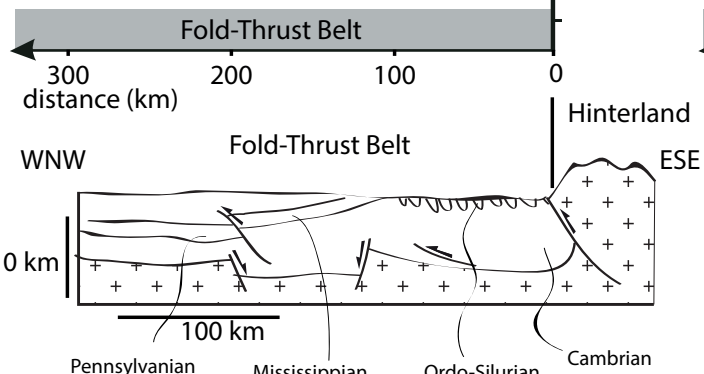

b) Zagros belt

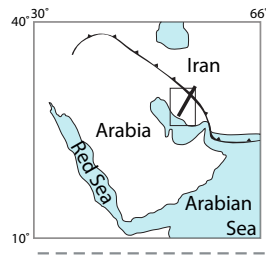

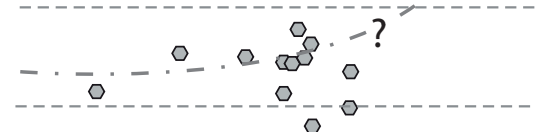

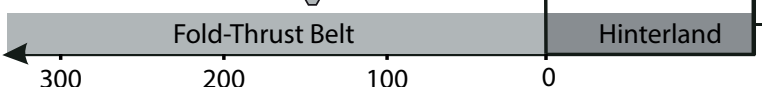

distance $(\mathrm{km})$

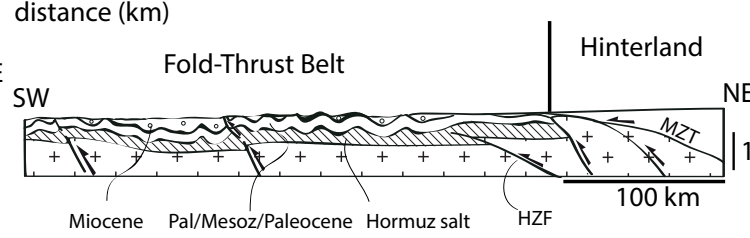

NE c) External Hellenides

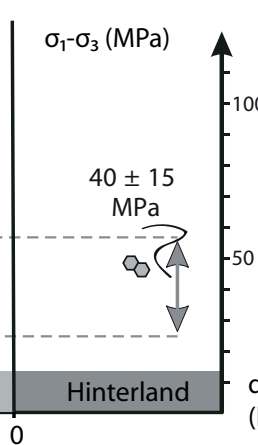

(km)

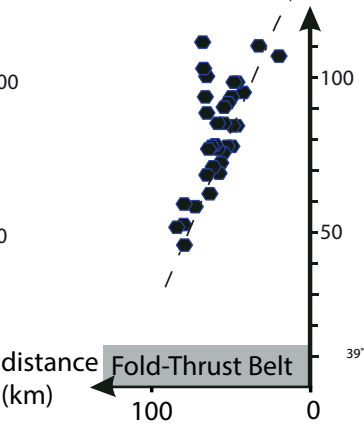

Fold-Thrust Belt

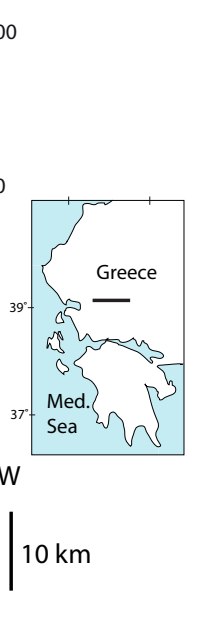

E Eocene-Oligocene $\mathrm{W}$

$10 \mathrm{~km}$ Triassic

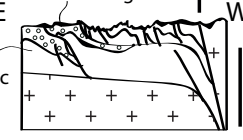

$10 \mathrm{~km}$ 


\section{LPS 1 Early-folding stage 1}

LPS 2 Early-folding stage 2

LPS 3 Early-folding stage 3

Folding

Late Stage Fold
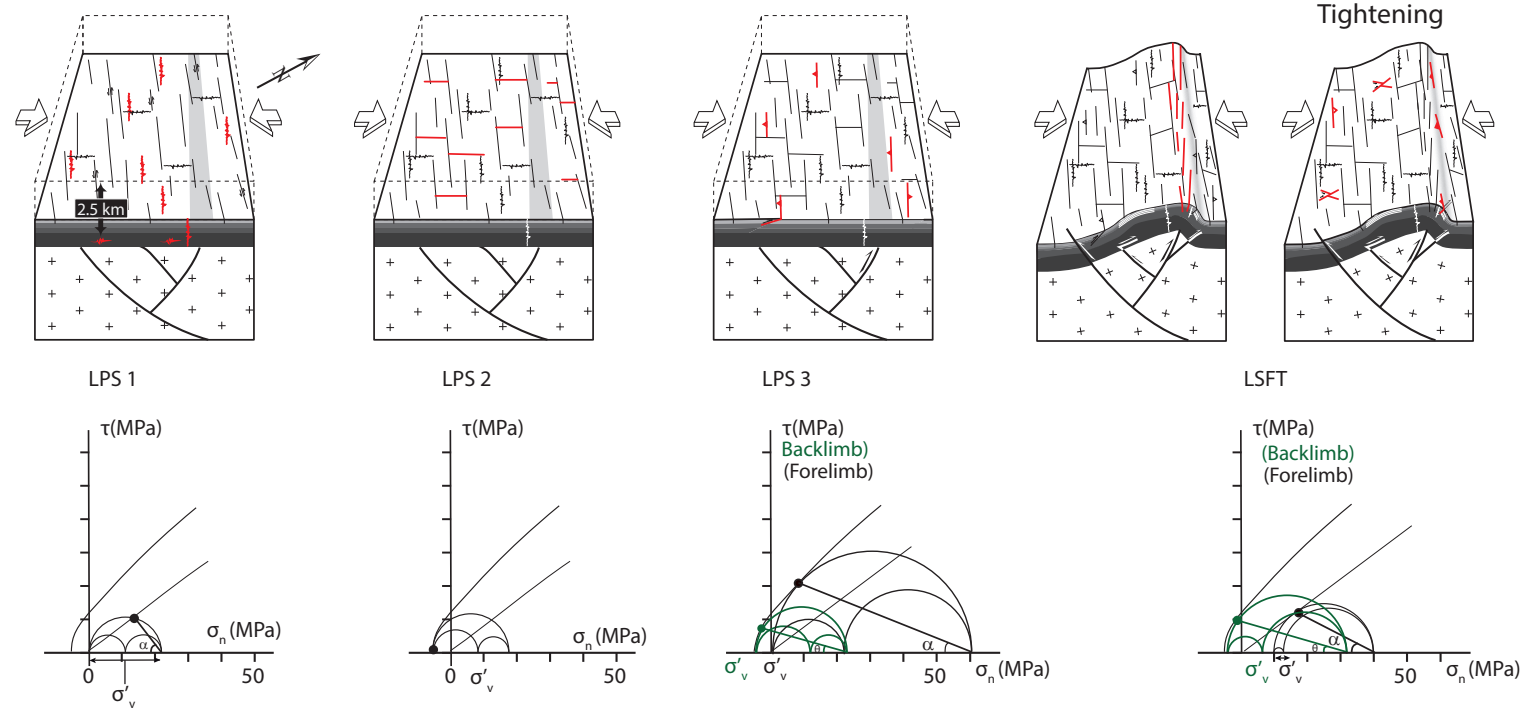

b) Monte Nero Anticline

LPS 1 Pre-folding stage

LPS 2 Early-folding stage

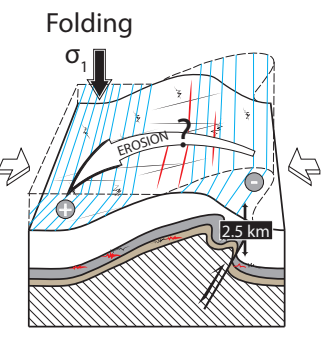

Late Stage Fold Tightening
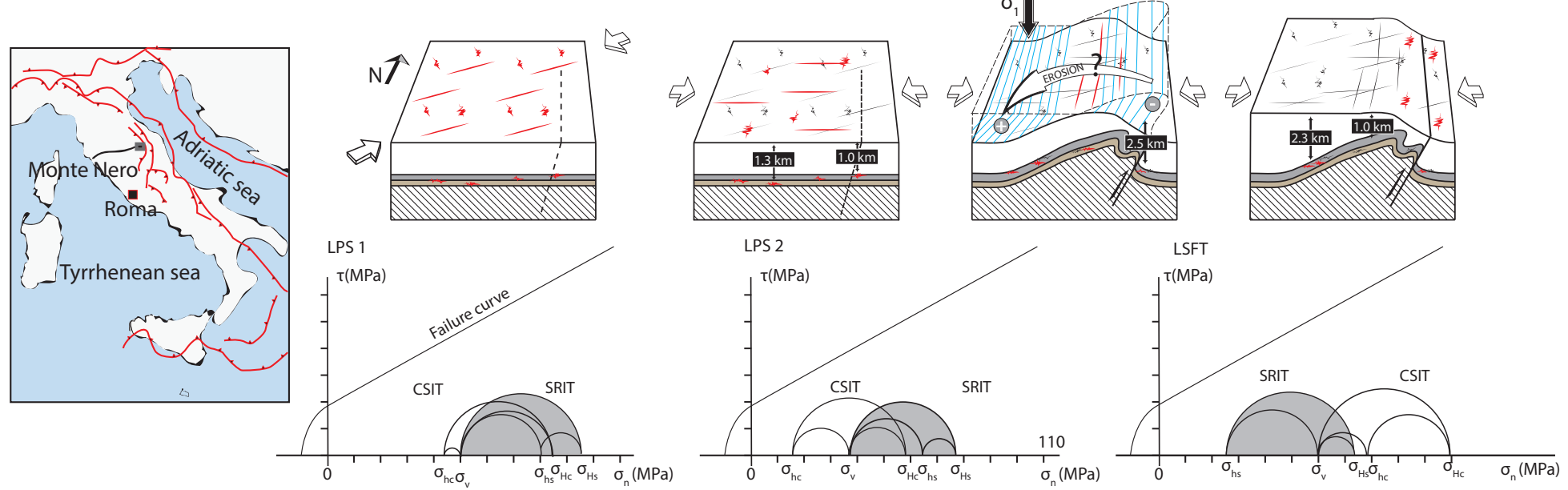


\section{Figure 5}

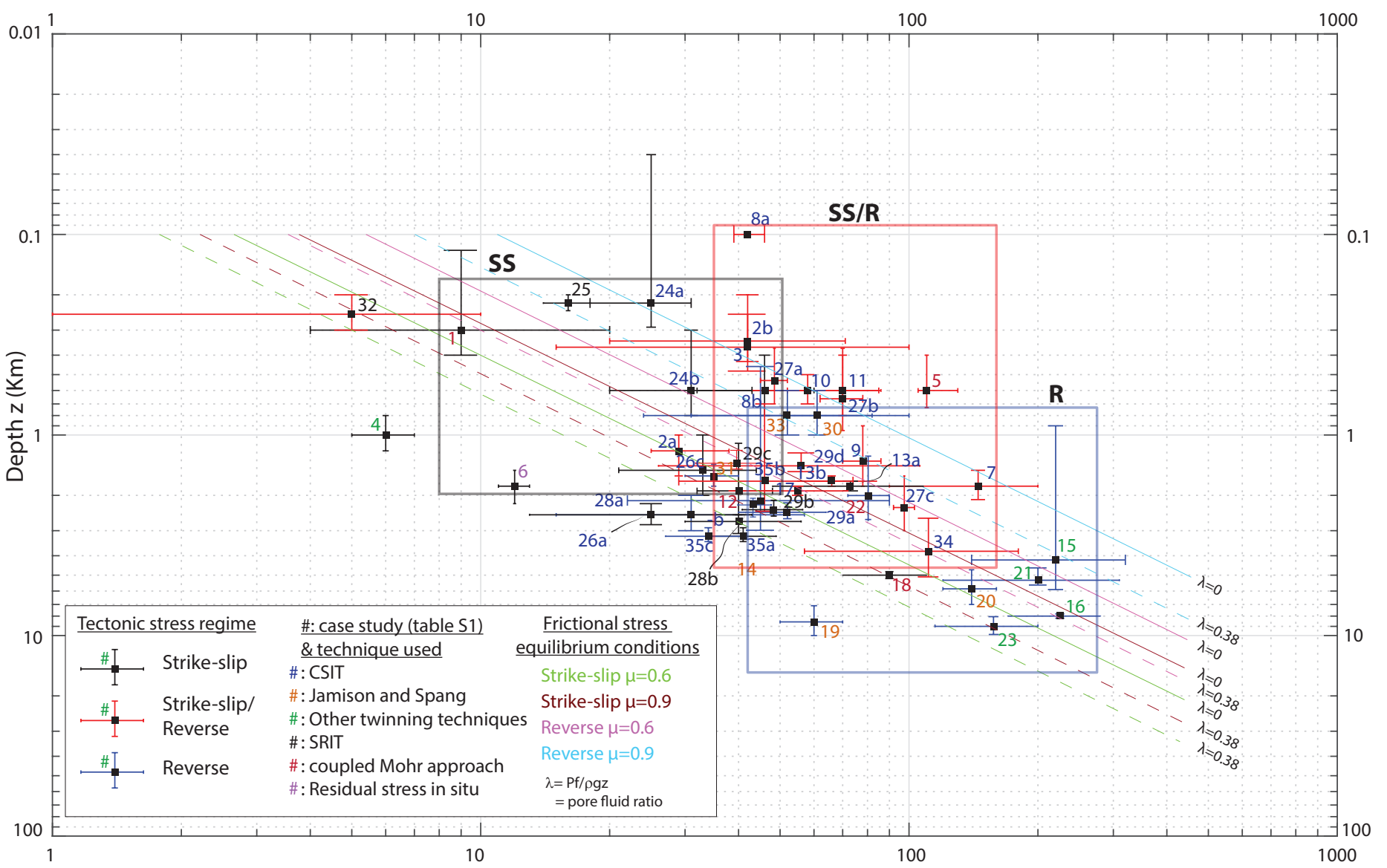


Table S1. Litterature review of paleopiezometric studies in the fold-and-thrust belts and sedimentary basin.

\begin{tabular}{|c|c|c|c|c|c|c|c|c|}
\hline \multirow{2}{*}{$\#$} & \multirow{2}{*}{ Case studies } & \multirow{2}{*}{ Paleopiezometric Techniques } & \multicolumn{2}{|c|}{ Differential stress (Mpa) } & \multicolumn{2}{|c|}{ Depth estimates (m) } & \multirow{2}{*}{ Regime } & \multirow{2}{*}{ Authors ${ }^{1}$} \\
\hline & & & mean $\left(\sigma_{1}-\sigma_{3}\right)$ & range $\left(\sigma_{1}-\sigma_{3}\right)^{*}$ & mean depth & range depth* & & \\
\hline 1 & Causses (France) & Mohr Approach (Faults) & 9 & {$[4-20]$} & 300 & {$[200-480]$} & SS & Rispoli \& Vasseur, 1983 \\
\hline $2 a$ & Zagros (Oman) & CSIT & 29 & [25-38] & 1200 & [800-1400] & $R / S S$ & Lacombe et al., 2007 \\
\hline $2 b$ & Zagros (Oman) & CSIT & 42 & [20-71] & 340 & {$[250-480]$} & $R / S S$ & Lacombe et al., 2007 \\
\hline 3 & Taiwan & CSIT & 42 & [15-100] & 365 & [250-480] & SS & Lacombe, 2001 \\
\hline 4 & Appalachian Plateau (USA) & $\mathrm{DD}$ & 6 & [5-7] & 1000 & {$[800-1200]$} & SS & Engelder, 1982 \\
\hline 5 & Germany & Mohr Approach (Faults) & 110 & [105-130] & 600 & {$[470-800]$} & $R / S S$ & Bergerat et al., 1985 \\
\hline 6 & Appalachian Plateau (USA) & Residual stress in situ & 12 & [11-13] & 1800 & [1400-2100] & SS & Engelder and Geiser, 1984 \\
\hline 7 & Taiwan $\mathrm{W}$ & CSIT & 145 & [90-200] & 1800 & [1500-2100] & $\mathrm{RR} / \mathrm{SS}$ & Lacombe, 2001 \\
\hline $8 a$ & Burgundy (France) & CSIT & 42 & [39-46] & 100 & [0-200] & $\mathrm{R} / \mathrm{SS}$ & Lacombe and Laurent, 1992 \\
\hline $8 b$ & Burgundy (France) & CSIT & 46 & [32-60] & 600 & {$[400-800]$} & SS & Lacombe and Laurent, 1992 \\
\hline 9 & Pyrenees (France) & CSIT & 78 & [70-86] & 1350 & [900-1800] & $R / S S$ & Tourneret and Laurent, 1990 \\
\hline 10 & Provence & CSIT & 58 & [43-86] & 600 & {$[500-700]$} & $R / S S$ & Lacombe et al., 1991 \\
\hline 11 & Taiwan W & CSIT & 70 & [52-85] & 600 & {$[400-800]$} & $R / S S$ & Lacombe, 2001 \\
\hline 12 & Morocco & Mohr Approach (Faults) & 40 & [32-48] & 1900 & [1300-2700] & SS & Petit, 1976 \\
\hline $13 a$ & Paris basin (France) & CSIT & 73 & [48-108] & 1800 & [1700-1900] & SS & Lacombe et al., 1994 \\
\hline $13 b$ & Paris basin (France) & CSIT & 66 & [55-84] & 1700 & [1600-1800] & $R / S S$ & Lacombe et al., 1994 \\
\hline 14 & Subalpine chain (France) & JS & 45 & {$[22-90]$} & 4200 & [2500-7500] & $\mathrm{R}$ & Ferrill, 1998 \\
\hline 15 & Subalpine chain (France) & $\mathrm{RR}$ & 220 & {$[140-320]$} & 4200 & {$[2500-7500]$} & $\mathrm{R}$ & Ferrill, 1998 \\
\hline 16 & Cantabrian (Spain) & $\mathrm{RR}$ & 225 & [170-280] & 8000 & [7800-8200] & $\mathrm{R}$ & Rowe and Rutter, 1990 \\
\hline 17 & Thailand & CSIT & 55 & [38-72] & 1900 & [1800-2000] & $R / S S$ & Arboit et al., 2017 \\
\hline 18 & Massif Central (France) & Mohr Approach (Faults and FIP) & 90 & [70-110] & 5000 & {$[4800-5200]$} & SS & Lespinasse \& Cathelineau, 1995 \\
\hline 19 & Pyrenees (Spain) & JS & 60 & [50-68] & 8550 & [7100-10000] & $\mathrm{R}$ & Holl and Anastasio, 1995 \\
\hline 20 & Rocky (Canada) & JS & 140 & [125-155] & 5850 & {$[4700-7000]$} & $\mathrm{R}$ & Jamison and Spang, 1976 \\
\hline 21 & Alps (Switzerland) & DD & 200 & [120-310] & 5300 & [5000-6000] & $\mathrm{R}$ & Pfiffner, 1982 \\
\hline 22 & South Korea & Mohr Approach (Faults) & 80,6 & [72-88] & 2000 & [1300-2700] & $\mathrm{R}$ & Choi et al., 2013 \\
\hline 23 & Pioneer landing (USA) & Dolomite twins JS/RR & 157,5 & [115-200] & 9000 & [8000-10000] & $\mathrm{R}$ & Newmann, 1994 \\
\hline $24 a$ & Lorraine (France) & CSIT & 25 & [18-31] & 220 & [150-400] & SS & Rocher et al., 2004 \\
\hline $24 b$ & Lorraine (France) & CSIT & 31 & [20-43] & 600 & [400-900] & SS & Rocher et al., 2004 \\
\hline 25 & Swabian Jura (Germany) & SRIT & 16 & [14-18] & 220 & [200-240] & SS & Ebner et al., 2010 \\
\hline $26 b$ & Bighorn Basin (USA) & CSIT & 31 & [18-45] & 2500 & [2000-3000] & $R / S S$ & Amrouch et al., 2010 \\
\hline $26 c$ & Bighorn Basin (USA) & CSIT & 33 & [21-44] & 1500 & [1000-2000] & SS & Amrouch et al., 2010 \\
\hline $26 a$ & Bighorn Basin (USA) & CSIT & 25 & [13-43] & 2500 & [2200-2800] & SS & Amrouch et al., 2010 \\
\hline $27 a$ & Hellenides (Greece) & CSIT & 48,5 & [45-52] & 535 & [370-700] & $\mathrm{R}$ & Xypolias \& Koukouvelas, 2005 \\
\hline $27 b$ & Hellenides (Greece) & CSIT & 70 & [62-78] & 660 & {$[370-950]$} & $\mathrm{R}$ & Xypolias \& Koukouvelas, 2005 \\
\hline $27 c$ & Hellenides (Greece) & CSIT & 97,5 & [92-103] & 2300 & {$[1600-3000]$} & $\mathrm{R}$ & Xypolias \& Koukouvelas, 2005 \\
\hline $28 a$ & Monte nero (Italy) & CSIT & 40 & {$[30-56]$} & 2100 & [1600-2500] & SS & Beaudoin et al., 2016 \\
\hline $28 b$ & Monte nero (Italy) & SRIT & 44 & [40-48] & 2100 & [1600-2500] & $\mathrm{R}$ & Beaudoin et al., 2016 \\
\hline $29 a$ & Monte nero (Italy) & CSIT & 52 & [40-64] & 2500 & [2000-2500] & $\mathrm{R}$ & Beaudoin et al., 2016 \\
\hline $29 b$ & Monte nero (Italy) & SRIT & 48 & [44-52] & 2500 & [2000-2500] & SS & Beaudoin et al., 2016 \\
\hline $29 c$ & Monte nero (Italy) & SRIT & 39 & [34-43] & 1600 & {$[1000-1700]$} & $R / S S$ & Beaudoin et al., 2016 \\
\hline $29 d$ & Monte nero (Italy) & CSIT & 56 & [26-106] & 1600 & [1000-1700] & $R / S S$ & Beaudoin et al., 2016 \\
\hline 30 & Ouachita (USA) & JS & 61 & [24-82] & 800 & {$[600-1000]$} & $\mathrm{R}$ & Craddock et al., 1993 \\
\hline 31 & Appalachian (USA)** & JS & 35 & [30-40] & 1600 & [1400-1800] & $\mathrm{R}$ & Craddock et al., 1993 \\
\hline 32 & Paris basin (France) & SRIT & 5 & [1-10] & 250 & [200-300] & SS & Rolland et al., 2014 \\
\hline 33 & Appalachian (USA) & JS & 52 & [31-100] & 800 & {$[600-1000]$} & $\mathrm{R}$ & Hnat and van der Pluijm, 2011 \\
\hline 34 & Albania & CSIT & 111 & [57-180] & 3800 & [2500-5000] & $R / S S$ & Lacombe et al., 2009 \\
\hline $35 a$ & Bighorn Basin (USA) & CSIT & 41 & [34-49] & 3200 & [3000-3500] & SS & Beaudoin et al., 2012 \\
\hline $35 b$ & Bighorn Basin (USA) & CSIT & 46 & [29-74] & 1700 & [1000-2700] & $R / S S$ & Beaudoin et al., 2012 \\
\hline $35 c$ & Bighorn Basin (USA) & CSIT & 34 & [27-41] & 3200 & [3000-3500] & $\mathrm{R}$ & Beaudoin et al., 2012 \\
\hline
\end{tabular}

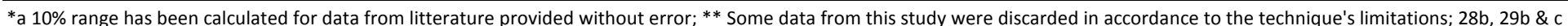
reevaluated after Beaudoin et al., 2016

CSIT: Calcite Stress Inversion Technique; JS: Jamison and Spang; RR: Rowe and Ruther; DD: Dislocation Density in Calcite; SRIT: Stylolite Roughness Inversion Technique

${ }^{1}$ By order of appearance: Rispoli \& Vasseur, 1983.Tectonophysics, 93, 169-184; Lacombe, 2007.Journal of Structural Geology, 29, 86-99; Lacombe, 2001. Tectonics, 20, 834-849;Engelder, 1982. Tectonics, 1, 161-177; Bergerat et al., 1985. Geologische Rundschau 74, 311-320; Engelder \& Geiser, 1984. Journal of Geophysical Research: Solid Earth, 89, 9365-9370; Lacombe \&

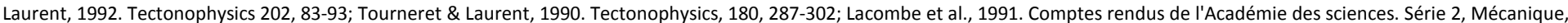
Physique, Chimie, Sciences de l'univers, Sciences de la Terre, 313, 1187-1194; Petit, 1976. PhD thesis. Université des Sciences et Techniques du Languedoc; Lacombe et al., 1994. PeriTethyan Platforms, 197-210; Ferrill, 1998. Tectonophysics, 285, 77-86; Rowe \& Rutter, 1990. Journal of Structural Geology, 12, 1-17; Arboit et al., 2017. Tectonophysics, 710, 266-276; Lespinasse \& Cathelineau, 1995. Journal of Geophysical Research: Solid Earth, 100, 3895-3904; Holl \& Anastasio, 1995. Journal of Structural Geology, 17 , 357-369; Jamison \& Spang, 1976. Geological Society of America Bulletin, 87, 868-872; Pfiffner, 1982. Journal of Structural Geology, 4, 429-442; Choi et al., 2013. Bulletin de la Société Géologique de France 184, 467-484; Newman, 1994. Journal of Structural Geology 16, 1589-1601; Rocher et al., 2004. Tectonophysics, 387, 1-21; Ebner et al., 2010. Journal of Geophysical Research, 115, B06403; Amrouch et al., 2010. Geophysical Journal International, 182, 1105-1123; Xypolias \& Koukouvelas, 2005. Episodes, 28, 245-251; Beaudoin et al., 2016. Tectonics, 35, 1687-1712; Craddock et al., 1993.

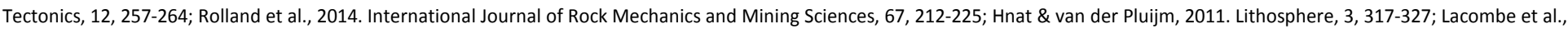
2009. Tectonophysics, 475, 128-141; Beaudoin et al, 2012. Tectonophysics, 576-577, 20-45. 